\title{
Differential object marking and Scales: Insights from Romance diachrony
}

\author{
Monica Alexandrina Irimia and Anna Pineda*
}

\begin{abstract}
This paper addresses a generally ignored counterexample to the Scales, comparing Old Catalan and Old Romanian on the one hand to Old Spanish on the other hand. Contrary to widely assumed marking hierarchies, Old Catalan/Old Romanian $3^{\text {rd }}$ person pronouns show differential object marking, to the exclusion of or to a higher degree than $1^{\text {st }} / 2^{\text {nd }}$ persons. We propose these patterns can be straightforwardly derived once we pin down micro-parameters in the composition of Romance DPs and the consequences various types of perspectival/sentience features have on the syntactic licensing of arguments.
\end{abstract}

Keywords. differential object marking; Romance languages; (Old) Romanian; (Old) Catalan; (Old) Spanish; animacy; personal pronouns

1. Introduction. Differential object marking (DOM) is a split in the morpho-syntactic marking of objects based on animacy, specificity, topicality, etc. (Comrie 1989, Bossong 1991, Aissen 2003, López 2012, a.o.). In several Romance languages, animacy is the broad regulating factor (Torrego 1998, Rodríguez-Mondoñedo 2007, López 2012, Ormazabal and Romero 2013a, a.o.). As we see in (1)a vs. (1)b, (definite) animate direct objects in modern Spanish need special marking in the form of the locative/dative preposition $a$ :
Modern Standard Spanish
a. He encontrado *(a) la niña. have.1SG found DOM $^{1}$ DEF.F.SG girl 'I have found the girl.'
b. He encontrado (*a) el libro. have.1SG found DOM DEF.M.SG book 'I have found the book.' (Ormazabal and Romero 2013a, ex.1 a, b)

Based on cross-linguistic regularities, it can be safely concluded that certain specifications on a nominal are more likely to be signalled via dedicated morphology. For example, pronouns or proper names normally require special marking in a wide variety of genetically unrelated languages. Building on the pioneering observations in Silverstein (1976), and their subsequent formalization in Aissen (2003), a.o., recent research has put forward well-defined hierarchies, also known as Scales, of the type schematically illustrated in (2). Within these accounts, the higher an

\footnotetext{
* We would like to thank Giuseppe Longobardi, András Bárány, Cristina Guardiano, M.T. Espinal. Adam Ledgeway, Rita Manzini, the audiences at DiGS 20 (York University), Going Romance 32 (Utrecht), LSA 2019 Annual Meeting, as well as several anonymous reviewers for their feedback and discussion on various points addressed in this paper. All errors and mistakes are our own. Funding - First author: the ERC grant \# 295733 LanGeLin (PI Giuseppe Longobardi) and a research grant offered by Università di Modena e Reggio Emilia. Second author: the postdoctoral research fellowship Juan de la Cierva-ncorporación and the research project FFI2014-56968-C4-1-P (IJCI-201630474, Ministerio de Economía y Competitividad, Spanish Government).

Authors: Monica Alexandrina Irimia, Università di Modena e Reggio Emilia (irimiamo@ unimore.it), Anna Pineda, Universitat Pompeu Fabra (anna.pineda@upf.edu).

${ }^{1}$ Abbreviations: $\mathrm{ACC}=$ accusative, $\mathrm{AOR}=$ aorist, $\mathrm{CL}=$ clitic, $\mathrm{COND}=$ conditional, $\mathrm{DAT}=$ dative, $\mathrm{DEF}=$ definite, $\mathrm{DOM}=$ differential object marking, $\mathrm{F}=$ feminine, $\mathrm{FUT}=$ future, $\mathrm{IMP}=$ imperative, $\mathrm{IMPF}=$ imperfect, $\mathrm{INF}=$ infinitive, $\mathrm{M}=$ masculine, $\mathrm{N}=$ neuter, $\mathrm{NOM}=$ nominative, $\mathrm{PL}=$ plural, $\mathrm{PRT}=$ participle, $\mathrm{PST}=$ past, $\mathrm{REFL}=$ reflexive $, \mathrm{REL}=\mathrm{relative}, \mathrm{SG}=$ singular, $\mathrm{SBJV}=$ subjunctive, $1=$ first person, $2=$ second person, $3=$ third person.
} 
object is on the Scale (e.g., 1/2 person pronoun), the higher the differential marking probability (Silverstein 1976, Aissen 2003, Næss 2004, Darlymple and Nikolaeva 2011, a.o.). In this paper, we will mostly focus on the Animacy/person Scale and the Specificity/definiteness Scale.

(2) TYPES OF SCALES (based on Silverstein 1976, Aissen 2003, a.o.)

(a) Animacy/person: $1 / 2>3>$ proper name $>$ human $>$ animate $>$ inanimate

(b) Specificity/definiteness: pronoun $>$ name $>$ definite $>$ specific indefinite $>$ non-specific

(c) Topic accessibility scale: active $>$ accessible $>$ unused $>$ brand-new anchored $>$ brand - new unanchored (Darlymple \& Nikolaeva 2011)

(d) High transitivity: proper name > person denoting noun > animate DP > concrete DP > DP in the singular > countable DP > referential/definite DP (Næss 2004, a.o.)

(e) Affectedness more affected $>$ affected $>$ less affected (Næss 2004, a.o.)

A common explanation for this state of affairs is the functionalist one, stemming from Comrie (1989). Generally, animate DPs or $1 / 2$ persons are more canonical agents than patients. If an object, on the other hand, bears these specifications in a (di)transitive frame, it must be signaled overtly so that it can be distinguished from the subject (agent) of a clause. The objects that bear differential marking are, in a sense, upgraded or re-ranked, becoming more similar to prototypical subjects; thus, they need to be signaled by special morphology so they can be correctly interpreted as objects, and not as subjects.

The diachronic study of Romance DOM has overwhelmingly shown that the special prepositional marking has started with objects higher on the Scales (e.g. $1^{\text {st }}$ and $2^{\text {nd }}$ personal pronouns, proper names, human DPs, etc.) and then progressively extended to those lower down. With respect to personal pronouns, $1^{\text {st }} / 2^{\text {nd }}$ persons are systematically claimed to be the strongest DOM triggers (Rohlfs 1971, Roegiest 1979, Sornicola 1997, Bossong 1991, a.o.). In this paper we present some counterexamples to this generalization. We start from previously unexplored differences between Old Spanish (OS), on the one hand, and Old Catalan (OC)/ Old Romanian (OR), on the other hand. In OC/OR, classes lower down on the Scales show DOM to the exclusion of higher ones, contrary to what the Scales would predict. In particular, in OC/OR, $3^{\text {rd }}$ person pronouns show DOM to the exclusion of $1^{\text {st }} / 2^{\text {nd }}$ persons ${ }^{2}$.

2. DOM in Old Romance. In this section we will present in more detail the problems OC and OR pose to accounts based on the above-mentioned Scales. In order to better frame the discussion, we will introduce first OS, a language where DOM respects the Scales. Diachronic studies performed on OS corpora have claimed that personal pronouns have been differentially marked from the very beginning, systematically, and with no exception. Some examples are illustrated in (3)-(4); relevant data and analysis can be found in contributions such as Pensado (1995: 19), Company (2002: 207-208), von Heusinger \& Kaiser (2005: 35-36, 41), Laca (2006: 426, 469), a.o.

\section{Old Spanish}

a. e ssi fuéredes vençidos, non rebtede a nós and if be.COND.2PL defeated not blame.IMP.2PL DOM us 'But if you are defeated you are not to blame us.'

$\left(12^{\text {th }}\right.$ c., Cid, 3566, apud von Heusinger and Kaiser 2005)

${ }^{2}$ OC and OR texts show other counterexamples to Scales, for example animate nouns or proper names carrying differential object marking to the exclusion of $\left(1^{\text {st }} / 2^{\text {nd }}\right.$ person $)$ pronouns. For lack of space, we only discuss the problem of $3^{\text {rd }}$ person pronouns here. 
b. Dios salve a nuestros amigos e a vós más señor, God save.SBJV.3SG DOM our friends and DOM you more lord 'May God save our friends and you above all, my lord.'

(12 ${ }^{\text {th }}$ c., Cid, 3038, apud Ramsden 1961: 49)

(4) a. ellos comdes gallizanos a él tienen por señor.

they counts Galicians DOM he have.3PL as lord

'They, Galician counts, have him as lord.'

b. todos a él guardavan.

(12 $2^{\text {th }}$ c., Cid, 2926, apud Ramsden 1961: 48)

all DOM he observe.IPFV.3PL

'They all observed him.'

(13 ${ }^{\text {th }}$ c., Poema de Fernán González 553b, apud Ramsden 1961: 48)

In OC (from the $11^{\text {th }}$ to the $16^{\text {th }}$ centuries), however, it does not seem to be the case that DOM consolidated first with $1^{\text {st }} / 2^{\text {nd }}$ person and then extended to $3^{\text {rd }}$ person. In (5) we provide some examples from the chivalry novel Curial e Güelfa, where several $3^{\text {rd }}$ person pronouns show DOM (5)a-b, whereas $1^{\text {st }}$ and $2^{\text {nd }}$ pronouns tend to lack it (5)c-d:

(5) Old Catalan - Curial e Güelfa, $15^{\text {th }} \mathrm{c}$.

a. vós havets honrat a ell. you.2PL have.2PL honoured DOM he

'You have honored him.'

b. ell e un companyó seu combatrían a ell. he and a companion his fight.COND.3PL DOM he 'You and a mate of his would fight him.'

c. ¿què ha mogut tu e ton companyó a...? what has moved you and your companion to 'What compelled you and your mate to...'

d. aquella senyora, qui mira nosaltres... that lady who look.3sG we

'That lady, who watches us...'

An overview of the occurrences of DOM in this novel shows that the contrast is quite robust:

\begin{tabular}{|c|c|c|}
\hline & NO DOM & DOM \\
\hline $1^{\text {st }} 2^{\text {nd }}$ & 4 & 5 \\
$\mathrm{sg} / \mathrm{pl}$ & $(44,4 \%)$ & $(55,5 \%)$ \\
\hline $\mathbf{3}^{\text {rd }} \mathbf{s g} / \mathbf{p l}$ & 1 & $\mathbf{5}$ \\
& $(16,7 \%)$ & $(\mathbf{8 3 , 3 \%})$ \\
\hline
\end{tabular}

Table 1. Curial e Güelfa, 15th century. First 30.000 words.

A similar pattern is found in other works from the $14^{\text {th }}$ and $15^{\text {th }}$ centuries (Tables 2-5); later corpora show that from the late $15^{\text {th }} \mathrm{c}$. onwards, DOM is becoming systematic with all strong (personal) pronouns, mirroring the picture seen in Modern Catalan, as well as in most modern Romance varieties. A similar observation holds for the transition from Old Romanian to Modern Romanian (MR), as we discuss in the next subsection. 


\begin{tabular}{|c|c|c|}
\hline & NO DOM & DOM \\
\hline $1^{\text {st }} / 2^{\text {nd }} \mathrm{sg} / \mathrm{pl}$ & $\begin{array}{c}2 \\
(100 \%)\end{array}$ & 0 \\
\hline $3^{\text {rd }} \mathbf{s g} / \mathbf{p l}$ & $\begin{array}{c}6 \\
(66,7 \%)\end{array}$ & $\begin{array}{c}\mathbf{3} \\
(\mathbf{3 3 , 3} \%)\end{array}$ \\
\hline
\end{tabular}

Table 2. Novel-letes Hongria, 14th century. Entire text [9.000 words]

\begin{tabular}{|c|c|c|}
\hline & NO DOM & DOM \\
\hline $1^{\text {st }} / 2^{\text {nd }}$ & 9 & 5 \\
$\mathrm{sg} / \mathrm{pl}$ & $(64,3 \%)$ & $(35,8 \%)$ \\
\hline $\mathbf{3}^{\text {rd }} \mathbf{s g} / \mathbf{p l}$ & 1 & $\mathbf{4}$ \\
& $(20 \%)$ & $(\mathbf{8 0 \%})$ \\
\hline
\end{tabular}

Table 4. Epistolari, 14th century. First 30.000 words.

\begin{tabular}{|c|c|c|}
\hline & NO DOM & DOM \\
\hline $\begin{array}{c}1^{\text {st }} / 2^{\text {nd }} \\
\mathrm{sg} / \mathrm{pl}\end{array}$ & $\begin{array}{c}3 \\
(100 \%)\end{array}$ & 0 \\
\hline $3^{\text {rd }} \mathbf{s g} / \mathbf{p l}$ & 0 & $\mathbf{2}$ \\
& & $(\mathbf{1 0 0 \%})$ \\
\hline
\end{tabular}

Table 3. Clams $i$ crims, 14th century. First 30.000 words.

\begin{tabular}{|c|c|c|}
\hline & NO DOM & DOM \\
\hline $1^{\mathrm{st}} / 2^{\text {nd }}$ & 9 & 3 \\
$\mathrm{sg} / \mathrm{pl}$ & $(75 \%)$ & $(25 \%)$ \\
\hline $\mathbf{3}^{\text {rd }} \mathbf{s g} / \mathbf{p l}$ & 0 & $\mathbf{2}$ \\
& & $(\mathbf{1 0 0 \%})$ \\
\hline
\end{tabular}

Table 5. Epistolari, 15th century. First 30.000 words.

The data above pose several problems to accounts in terms of Scales. The latter would predict $1^{\text {st }}$ and $2^{\text {nd }}$ person pronouns to be stronger DOM triggers than $3^{\text {rd }}$ person pronouns; we see exactly the opposite in OC. Therefore, an explanation is required. More importantly, the Catalan situation is replicated by OR, where the prominence of $3^{\text {rd }}$ person is seen in various texts, as discussed below.

2.1. DOM IN Old Romanian. Differential object marking is robust in OR texts (Mardale 2015, Avram and Zafiu 2017, Nicula Paraschiv 2017, Hill and Mardale 2017, a.o.), with animacy being a relevant factor at various stages. The most important difference from other Romance varieties is morphological. Although DOM uses a prepositional strategy, the marker is not homophonous with the dative; the locative preposition pe ('on)' or spre ('towards') ${ }^{3}$ with various allomorphs is used instead, as illustrated in the example below:

(6) Old Romanian

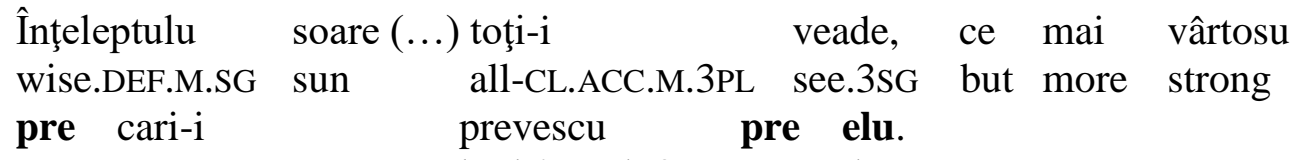

DOM REL.M.PL-DEF.M.PL look/watch.3PL DOM he

Lit: 'The wise sun sees everyone, especially those who watch him.'

'The wise sun sees everyone, especially the ones who look at it.'

$\left(C^{2}\right.$.1581:439, see also Nicula Paraschiv 2016)

The data we are concerned with come from texts dating from the early $16^{\text {th }}$ century, and probably indicating patterns from the late $15^{\text {th }}$ century. The attentive reader might have noticed that these texts are dated later than the $\mathrm{OC}$ ones; this is due to the fact that the first available written documents in OR are only seen in the $15^{\text {th }}$ century ${ }^{4}$. In the early $16^{\text {th }}$ century texts it appears that

\footnotetext{
${ }^{3}$ There are significant differences between the use of $p e$ in the first part of the $16^{\text {th }} \mathrm{c}$., and in texts written at the end of the $16^{\text {th }} \mathrm{c}$. (after 1580). There also differences between translations and original OR texts (Rosetti 1978, Mardale 2015, Pană-Dindelegan 2016, Avram and Zafiu 2017, a.o.).

${ }^{4}$ Agreed-upon parametrization of OR: i) first period of OR: the period of the earliest texts available (1500-1640); ii) second period of OR, characterized by increase in the number and stylistic range of texts (1640-1780); see especially Pană-Dindelegan (2016) for more details.
} 
$3^{\text {rd }}$ person pronouns show DOM, which is optional with $1^{\text {st }}$ and $2^{\text {nd }}$ person pronouns. von Heusinger and Onea (2008) have observed the same patterns, and the data in Table 6 below come from their paper. The two authors have examined a corpus formed of religious tests, mainly Bible translations ${ }^{5}$. The puzzling fact revealed by the data is that DOM is more robust with $3^{\text {rd }}$ person, as opposed to $1^{\text {st }}$ and $2^{\text {nd }}$ person. von Heusinger and Onea's (2008) results are included in Table 6 below; as we can see there, $3^{\text {rd }}$ person is differentially marked $97 \%$ of the times, while with $1^{\text {st }}$ and $2^{\text {nd }}$ person only $50 \%$ of the instances show the expected marking. Note that the two authors have only analyzed [+human] DPs in the class of $3^{\text {rd }}$ person pronouns (and nouns). The transition to MR has seen a regularization of obligatory differential marking to all pronouns.

\begin{tabular}{|c|c|c|}
\hline & NO DOM & DOM \\
\hline $1^{\text {st }} / 2^{\text {nd }} \mathrm{sg} / \mathrm{pl}$ & 5 & $\mathbf{5}$ \\
& $(50 \%)$ & $(50 \%)$ \\
\hline $3^{\text {rd }} \mathbf{s g} / \mathbf{p l}$ & 1 & $\mathbf{3 3}$ \\
& $(3 \%)$ & $(\mathbf{9 7 \%})$ \\
\hline
\end{tabular}

Table 6. Direct object marking with $p(r) e$ in $16^{\text {th }} \mathrm{c}$. Romanian (adapted from von Heusinger and Onea 2008, Table 1, page 77)

In conclusion, data from both OC and OR pose a problem to equating DOM to a Animacy/Person Scale of the type in (2)(a), repeated here under (7). The problem is that this Scale predicts $1^{\text {st }}$ and $2^{\text {nd }}$ person to be stronger triggers for the special marking than the $3^{\text {rd }}$ person. More simply put, the Scale predicts that if there is DOM, it should be more frequent with $1^{\text {st }}$ and $2^{\text {nd }}$ person than with $3^{\text {rd }}$ person. OR and OC show instead that $3^{\text {rd }}$ person, unexpectedly, appears to be more robust.

(7) Animacy/person: $1 / 2>3>$ proper name $>$ human $>$ animate $>$ inanimate

A simple explanation according to which these facts might be some exceptions that have to receive an independent explanation (i.e, errors in the data that have to be attributed to extralinguistic factors) is weakened from a variety of points of view. First, it is not clear why languages that have not been in close contact show precisely this pattern ${ }^{6}$. Second, other Old Romance varieties appear to lead to a similar conclusion, for example Old Sardinian. And third, the prominence of $3^{\text {rd }}$ person to the exclusion of $1^{\text {st }}$ and $2^{\text {nd }}$ person has also been documented for nonRomance varieties, as well as languages that are not Indo-European. As a simple illustration, in Kashmiri (Indo-Aryan), an animacy-based adpositional DOM is seen with $3^{\text {rd }}$ person, but not with $1^{\text {st }}$ and $2^{\text {nd }}$ persons ${ }^{7}$ (see especially Keine 2010). Outside Indo-European, Nikolaeva (2014) has noticed a similar problem for Tundra Nenets, and Darlymple and Nikolaeva (2011) for varieties of Khanty. Given this systematicity, the question is how such apparent exceptions are to be explained and what they tell us about the nature of DOM. In the next section, we examine the hypothesis put for forward by von Heusinger and Onea (2008), who connected the obligatoriness of DOM with $3^{\text {rd }}$ person to the need of signaling accusative case in the absence of dedicated inflectional morphology for the accusative case. We show that this assumption is problematic from several points of view.

\footnotetext{
${ }^{5}$ Bible A: Noul Testament de la Bălgrad (The New Testament from Bălgrad) - 1648, Transylvania; Bible B: Biblie V.T.N.T (Bible Old Testament and New Testament) - 1688, Walachia (Bucharest). See the Appendix for more details about the corpus.

${ }^{6}$ Romanian is a Southern Romance variety, while Catalan belongs to Western Romance; the two varieties are geographically separated by vast areas that contain other Romance varieties, as well as non-Romance languages.

7 The latter trigger a special type of object agreement (under certain conditions).
} 
3. An analysis in terms of accusative case doesn't work. von Heusinger and Onea (2008, p.79) have preliminarily proposed that the puzzling presence of DOM with $3^{\text {rd }}$ person could have a straightforward explanation if we look at the case morphology shown by the pronouns in (Old) Romanian. As seen in Table $7,1^{\text {st }}$ and $2^{\text {nd }}$ persons show distinct inflectional morphology for the nominative and the accusative ${ }^{8}$. The reasoning is as follows: given that for $1^{\text {st }}$ and $2^{\text {nd }}$ person case morphology clearly signals the accusative, DOM would not be necessary. The opposite holds for $3^{\text {rd }}$ person - here, the accusative and the nominative are homophonous. Thus, an independent morphological means is needed in order to signal the accusative use. This is precisely the function of the differential marking preposition, which disambiguates the accusative.

This explanation is appealing. However, there are several counterarguments to it. First, note that Table 7 only gives the MR patterns. In the $16^{\text {th }}$ century, the $3^{\text {rd }}$ person pronoun could also take distinct accusative morphology, the form sine, as seen in Table 8.

\begin{tabular}{|c|c|c|c|c|c|c|}
\hline \multirow{2}{*}{} & \multicolumn{3}{|c|}{ Singular } & \multicolumn{3}{c|}{ Plural } \\
\cline { 2 - 7 } & NOM & ACC & DAT & NOM & ACC & DAT \\
\hline $1^{\text {st }}$ person & eu & mine & mie & noi & noi & nouă \\
\hline $2^{\text {nd }}$ person & tu & tine & thie & voi & voi & vouă \\
\hline $3^{\text {rd }}$ person & M el & el & $l u i$ & ei & ei & lor \\
\cline { 2 - 8 } & F ea & ea & $e i$ & ele & ele & lor \\
\hline
\end{tabular}

Table 7. Morphology of personal pronouns in modern Romanian

\begin{tabular}{|c|cc|c|c|c|}
\hline \multirow{2}{*}{} & \multicolumn{2}{|c|}{ Singular } & \multicolumn{2}{c|}{ Plural } \\
\cline { 2 - 6 } & NOM & ACC & NOM & ACC \\
\hline $1^{\text {st }}$ person & eu & mene/menre & noi & noi \\
\hline $2^{\text {nd }}$ person & & tu & tine & voi & voi \\
\hline $3^{\text {rd }}$ person & $\mathrm{M}$ & elu & elu, sine & ei & ei \\
\cline { 2 - 6 } & F & ea & ea, sine & ele/eale & ele \\
\hline
\end{tabular}

Table 8. Morphology of personal pronouns in OR (16 ${ }^{\text {th }}$ century)

This morphology appears in OR texts with the DOM preposition, just like elu, which is homophonous between the nominative and the accusative. Excluding the form sine as a reflexive does not account for its behavior in OR texts, as this morphology does not seem to always carry a reflexive interpretation ${ }^{9}$. The contrasting examples in (8) from OR and (9), from (MR), show the difference.

(8) ca să poată hrăni pe sine. such SBJV can.SBJV.3SG feed.INF DOM he 'in order to be able to feed him.'

(OR, DÎ.1593: XCV)
ca să *(se)
poată
hrăni
(*pe) sine.
such SBJV
CL.REFL.ACC.3SG
can.SBJV.3SG feed.INF DOM
self.ACC

'in order to be able to feed himself.'

Second, distinct accusative morphology is only seen in the $1^{\text {st }} / 2^{\text {nd }}$ person singular. DOM as a case disambiguating strategy would predict that $1^{\text {st }} / 2^{\text {nd }}$ person plural should uniformly show DOM (just

\footnotetext{
${ }^{8}$ As well as the dative. Romanian is a Romance variety that has preserved the inflectional dative case seen in Latin.

${ }^{9}$ Note nevertheless that the presence of obligatory differential marking with the third person reflexive would be problematic in itself under the Scales mentioned.
} 
like $3^{\text {rd }}$ person) due to the NOM-ACC syncretism. But this is not what we get in the corpora. As we can see in the examples in (10), the $2^{\text {nd }}$ person plural voi is used without differential marking as a direct object ${ }^{10}$. The same holds with $1^{\text {st }}$ person plural. $3^{\text {rd }}$ person, on the other hand, shows up with differential object marking in the same texts:

(10)

Object pronouns in OR texts

a. Nemica voi să vatăme.

nothing.NOM you.PL SBJV hurt.SBJV.3.SG

'Let nothing hurt you.'

(CT. $\left.1560-1: 140^{\vee}\right)$

b. Lumea pre elu nu cunoscu.

people.NOM DOM he not recognize.PST.3SG

'People did not recognize him.'

(CT. $1560-1: 1^{\mathrm{v}}$ )

c. Va vindeca noi.

FUT.3SG heal we

'He will heal us.'

d. Surpa-l-va pre elu.

destroy-CL.ACC.M.3SG-FUT.3SG DOM he

'He will destroy him.'

$\left(\mathrm{CC}^{2} .1581: 23\right)$

Examples like (10)d raise a third type of problem. (Old) Romanian is one of the Romance varieties that show accusative clitic doubling with certain types of $\mathrm{DOM}^{11}$, as we see in example (10)d. Table 9 shows that clitics have both accusative and dative morphology. There are no nominative clitics. The crucial point is that the accusative function of the $3^{\text {rd }}$ person nominal is clearly signaled by the accusative clitic, as an indirect object DPs will automatically carry dative case inflection. Given this, it is not clear why differential marking would still be necessary ${ }^{12}$.

\begin{tabular}{|c|c|c|c|}
\hline & NOM & $\mathrm{ACC}$ & DAT \\
\hline $1^{\text {st }}$ person $\mathrm{sg}$ & $\mathrm{eu}$ & mine, mă, m- & mie, îmi, mi- \\
\hline $2^{\text {nd }}$ person $\mathrm{sg}$ & tu & tine, te, te- & ţie, îţi, ţi- \\
\hline \multirow[t]{2}{*}{$3^{\text {rd }}$ person $\mathrm{sg}$} & el & el, îl, -l, l- & lui, îi, i- \\
\hline & F ea & ea, $0,-0,0-,-0-$ & ei, îi, i- \\
\hline $1^{\text {st }}$ person $\mathrm{pl}$ & noi & noi, ne, -ne, -ne- & nouă, ne, ne-, -ne \\
\hline $2^{\text {nd }}$ person $\mathrm{pl}$ & voi & voi, vă, v- & vouă, vă, v- \\
\hline \multirow[t]{2}{*}{$3^{\text {rd }}$ person $\mathrm{pl}$} & ei & ei, îi, i-, -i, -i- & lor, le, -le, -le \\
\hline & ele & ele, le, -le, -le- & lor, le, -le, -le \\
\hline
\end{tabular}

Table 9. Morphology of tonic pronouns and clitics in Romanian

Similar problems are apparent in OC, where tonic pronouns only show distinct accusative morphology in the $1^{\text {st }}$ person singular. Table 10 presents the full paradigm. The disambiguation hypothesis would predict the obligatoriness of DOM with $2^{\text {nd }}$ and $3^{\text {rd }}$ persons. However, this is not what the data show. In the examples in (5) we have illustrated $3^{\text {rd }}$ person with DOM, but $1^{\text {st }}$ and $2^{\text {nd }}$ persons without DOM, despite the fact that NOM-ACC syncretism holds for $2^{\text {nd }}$ and $3^{\text {rd }}$ person.

\footnotetext{
${ }^{10}$ The verb tracks subject agreement in OR. Thus, in examples (10)a and (10)c the second person plural pronoun and respectively, the first person plural pronoun have a direct object function, despite the lack of differential morphology.

${ }^{11}$ In MR, clitic doubling of direct objects is obligatory in a variety of contexts, which include tonic forms of personal pronouns. The clitic double can only show accusatuve morphology, and is possible if DOM is also present.

12 The opposite is also relevant. As DOM signals ACC case, it is not clear why ACC clitic doubling would be necessary.
} 


\begin{tabular}{|c|cc|c|c|c|}
\hline \multirow{2}{*}{} & \multicolumn{2}{|c|}{ Singular } & \multicolumn{2}{c|}{ Plural } \\
\cline { 2 - 6 } & NOM & ACC & NOM & ACC \\
\hline $1^{\text {st }}$ person & jo & mi & nós/nosaltres & nós/nosaltres \\
\hline $2^{\text {nd }}$ person & \multicolumn{2}{|c}{ tu } & tu & vós/vosaltres & vós/vosaltres \\
\hline \multirow{2}{*}{$3^{\text {rd }}$ person } & M & ell & ell & ells & ells \\
\cline { 2 - 6 } & F & ella & ella & elles & elles \\
\hline
\end{tabular}

Table 10. Morphology of personal pronouns in Old Catalan

In conclusion, it seems that the problem is rather $3^{\text {rd }}$ person itself, and not the NOM/ACC homomorphism, with the need of DOM to disambiguate between subjects and objects. Importantly, despite the fact that $3^{\text {rd }}$ person objects can be disambiguated by clitic-doubling with dedicated accusative morphology (in OR), DOM is still needed. Thus, both OR and OC require an explanation, as Scales predict $1^{\text {st }} / 2^{\text {nd }}$ person to be stronger DOM triggers than $3^{\text {rd }}$ person. We sketch an analysis in the next section.

4. Steps towards an analysis. Under recent accounts, DOM is equated with structural Case/licensing. Objects that cannot show DOM are assumed to undergo (pseudo)-incorporation, as predicates (López 2012, Ormazabal and Romero 2013a, b, Kalin 2018, Levin 2019, a.o.). A simple representation is given below:

(11)

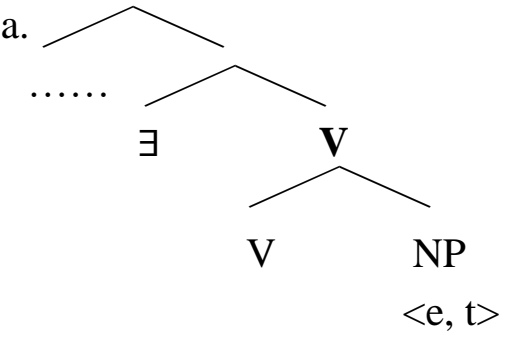

non-DOM objects (incorporation) b.

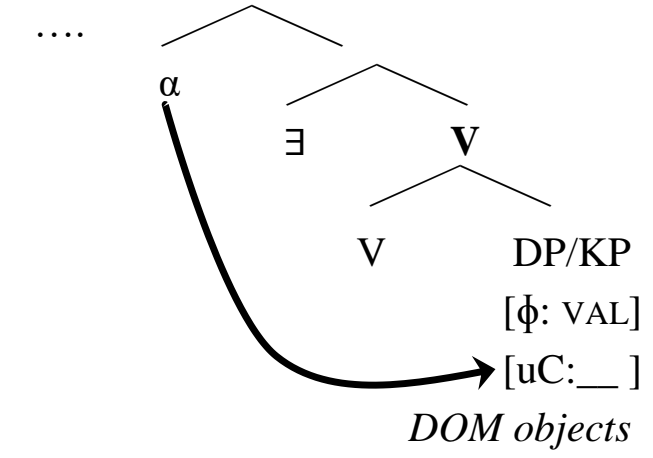

We build on these lines of research, as among the various formalizations for DOM they have the potential to explain the puzzle we are concerned with here; however, our claim is that DOM does not simply signal the difference between objects that undergo (pseudo-) incorporation (DOM-less ones) and objects that must be licensed in the syntax (DOM-ed). OR and OC provide evidence that the differential marker tracks an additional licensing operation on objects that have independent argumental status (and escape incorporation). More simply put, the differential marker is rather an argument licensing operation beyond Case (see also Cornilescu and Tigău 2017, Irimia 2018, a.o.). Thus, the typology of direct objects in OC and OR is a three-way one: a) objects that are not subject to licensing (11)a; b) objects that undergo licensing ${ }^{13}(11) \mathrm{b}$; c) objects that contain an

${ }^{13}$ OC provides further evidence for a three-way split in the marking of direct objects. A difference is made in the language between objects that can show up with no object agreement, objects that show object agreement (in number and gender on the participle in analytic past tenses), as well as objects that show differential marking, which is independent of object agreement. An example of object agreement wothout DOM is illustrated below; note that object agreement is not sensitive to animacy (the object in the example below is inanimate and cannot take DOM):

(i) Old Catalan - Matrimoni $\left(14^{\text {th }} \mathrm{c}\right.$.)

ell ... hac menjada la dita vianda

he....had eaten.F.SG DEF.F.S G said.F.SG meat.F.SG

'He has eaten the above-mentioned meat.' 
extra specification beyond $[\mathrm{uC}]$, as in (12). It is the latter objects that are differentially marked via the preposition.

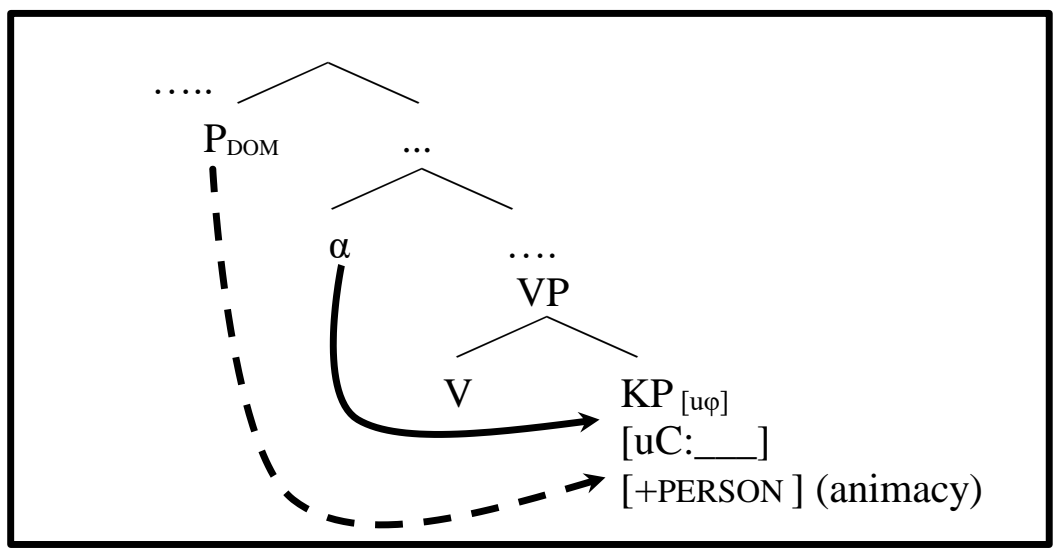

\section{DOM objects} ADDITIONAL

LICENSING

4.1. ASSUMPTIONS. The diagram in (12) indicates that we connect the additional licensing operation to the presence of a [+PERSON] feature. In this we follow and adjust accounts where animacy is seen as the reflex of [+PERSON] specification (Cornilescu 2000, Adger and Harbour 2007, Nevins 2007, Richards 2008, a.o.). As we have mentioned above, the correlation between animacy and adpositional differential marking is clear in both Old and modern Romance varieties that have differential marking ${ }^{14}$. The connection between animacy and [+PERSON] is represented in Table (11). We model this geometry after Harley and Ritter (2003), Nevins (2007) and Anagnostopoulou $(2003)^{15}$, a.o.:

\begin{tabular}{ll} 
PERSON/ANIMACY & FEATURES \\
\hline $1^{\text {st }}$ person & {$[+$ PERSON $](=[+$ PARTICIPANT $])$ speaker } \\
$2^{\text {nd }}$ person & {$[+$ PERSON $](=[+$ PARTICIPANT $])$ addressee } \\
$3^{\text {rd }}$ person $[+$ human,+ animate $]$ & {$[+$ PERSON $](=[+$ PARTICIPANT $])$} \\
\hline
\end{tabular}

Table 11. Person and animacy (building on Harley and Ritter 2002, Anagnostopoulou 2003)

One important piece of evidence supporting the presence of a [+PERSON] specification in the composition of differentially marked objects is related to PCC-type interactions they give rise to. The pioneering discussion in Ormazabal and Romero (2007) has demonstrated that certain contexts where combinations of two clitics are banned can be reduced to the need of animate pronominal elements to enter into an object agreement relationship with the relevant verbal material. A typical contrast from a Spanish leísta variety is illustrated below. As we see in (13)b, in these varieties, the direct object clitic must take differential morphology, in the form of dative marking, if it refers to an animate entity. Inanimate clitics take regular accusative morphology (13)a. What is further relevant to us are typical PCC (Person Case Constraint) configurations, where a dative clitic precedes an accusative clitic. The contrast in (14)b shows that configurations in which the differentially marked animate direct clitic and the indirect object clitic co-occur are ungrammatical. On the other hand, the example in (14)a contains a direct object with its regular accusative morphology and which can also be interpreted as an inanimate. This latter example is

\footnotetext{
${ }^{14}$ Although there are certain classes of inanimates which must be differentially marked, especially in modern Romance varieties. For simplicity and lack of space, we leave aside a detailed discussion of these classes.

${ }^{15}$ Note that not all accounts mentioned above assume a binary specification for [PERSON]. We use this feature notation for conveninece, but nothing hinges on it.
} 
grammatical, although it equally contains two clitics, one corresponding to the indirect object and the other one to the direct object. This indicates that animacy plays an important role in licensing operations; assuming that the relevant dative clitics contain a [+PERSON] feature which requires licensing (Anagnostopoulou 2003), the problem with (14)b could reduce to a configuration that contains two [+PERSON] features which require licensing, one corresponding to the dative clitic and the other one to the differentially marked animate clitic. As the structure contains only one relevant licenser, [+PERSON] of the higher argument (the indirect object dative) will undergo licensing; the lower [+PERSON] feature in the composition of the animate direct object clitic will remain unlicensed, leading to crash.

\section{Leísta Spanish}

Lo

vi.

CL.3ACC [-Animate] saw

'I saw it.'
b. Le
vi.
CL.3DAT $=$ DOM $_{[+ \text {Animate }]}$ Saw
'I saw him.

(14) PCC and animacy - Leísta Spanish
a. $\mathrm{Te}$
lo
di.
CL.2DAT CL.3ACC gave-1SG
'I gave it/him to you.'
b. *Te le di.
CL.2DAT CL.3DAT=DOM gave-1SG

Intended: 'I gave him to you.'

(Ormazabal and Romero 2007: 15/16)

One question we might raise about these examples is the following - the example in (14)b contains two clitics. The presence of a [+PERSON] feature is not surprising, at least for dative clitics. But the problematic issues we are addressing contain full pronouns for the $3^{\text {rd }}$ person (or full nominal DPs) which show overt adpositional differential morphology. The question is whether the latter cases also give rise to ungrammaticality. Given the restrictions in the corpora (that do not contain ungrammatical examples), we can test the data in the modern varieties. The full pronoun test gives the same results as the clitic contexts. In most Romance varieties that show DOM, full pronouns in direct object position must carry differential marking (as well as clitic doubling). Moreover, the overt form of the tonic pronoun for the $3^{\text {rd }}$ person is only possible if the referent is animate (Cardinaletti and Starke 1999, a.o.). Thus, the tonic pronoun configurations that would correspond to the contexts of the type in (14)b are ungrammatical in the relevant leísta Spanish dialects, as expected and as shown in (15):

(15) Leísta Spanish

$\begin{array}{lllll}* \text { Te } & \text { le } & \text { di } & \text { a } & \text { él. } \\ \text { CL.2DAT } & \text { CL.3DAT=DOM } & \text { gave.1SG } & \text { DAT=DOM } & \text { he } \\ \text { Intended: 'I gave him to you.' } & & & \end{array}$

In Romanian, the clitic PCC illustrates a me-first type. Thus, IO-DO clitic clusters only lead to ungrammaticality if the accusative clitic is first person ${ }^{16}$; also, (modern) Romanian does not exhibit dedicated morphology for animate clitics. Lack of relevant differentially marked

\footnotetext{
16 See the contrast between (i) and (ii):

Modern Romanian

(i) $*$ Tri m-a dat.

CL.2SG.DAT CL.1SG.ACC-has given Intended: 'He has given me to you.'
}

(ii)

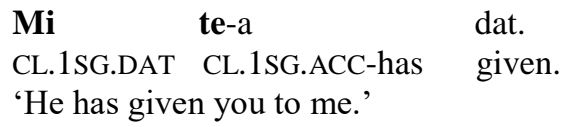


morphology for the accusative animate clitic is also a characteristic of Catalan. However, the same restrictions are salient in configurations that contain an indirect object clitic, as well as a full nominal which shows the adpositional differential marker. The ungrammatical Romanian example in (16) contains a differentially marked DPs, as well as dative clitic interpreted as a possessor dative; in order to obtain grammaticality, either the possessor dative or the differential marker must be removed. In both modern Spanish (17) and modern Catalan (18) a differentially marked DPs is ungrammatical if the structure contains an indirect object which is clitic doubled:

(16) Romanian

*Mi-a ajutat pe prieten.

CL.1SG.DAT-has helped DOM friend

Intended: 'S/he has helped my friend.'

(Literal: 'S/he to me has helped the friend.')

(17) Standard Spanish

Le enviaron (*a) los enfermos a la doctora.

CL.DAT.3SG sent.3.PL DOM DEF.M.PL sick people to DEF.F.SG doctor

'They sent the sick people to the doctor.' $\quad$ (Ormazabal and Romero 2013b: 8)

(18) Catalan

Li van enviar (*a) els malalts a la doctora.

CL.DAT.3SG sent.3.PL DOM DEF.M.PL sick.people to the doctor.F.SG

'They sent the sick people to the doctor.'

These types of data allow us to postulate that some $3^{\text {rd }}$ person DPs, namely animates that are differentially marked, contain a [+PERSON] feature that requires licensing, beyond [uC]. We can further work this out by assuming that the [+PERSON] feature correlated with animacy and spelled out as the prepositional [DOM] is a type of Sentience (Sundaresan 2018), or Perspective (Zubizarreta and Pancheva 2017, a.o.) representation. In some contexts, this feature needs anchoring to the discourse, just like [SPEAKER], [HEARER] (Nichols 2001, Béjar and Rezac 2009, a.o). Therefore, we can obtain the following possible geometries for $3^{\text {rd }}$ person, adapting Harley and Ritter (2002), a.o., as well as the 'DOM as [+PERSON]' hypothesis:

(19) a. Third person animate noun

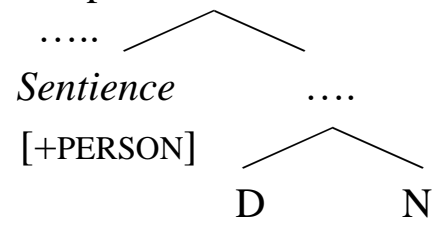

(20) a. Third person animate pronoun

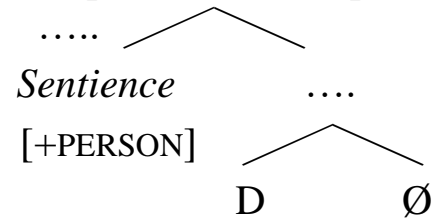

b. Third person inanimate noun

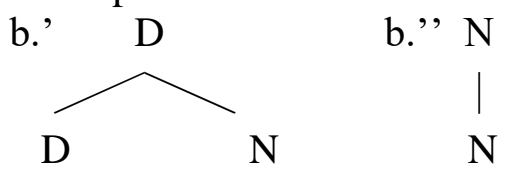

b. Third person inanimate pronoun

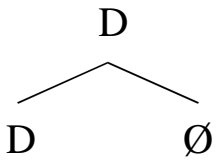

5. Animacy and discourse participants. Given the representations presented above, we can now turn to the problem raised by this paper, namely the unexpected presence of DOM with $3^{\text {rd }}$ person to 
the exclusion of $1^{\text {st }}$ and $2^{\text {nd }}$ person. We have seen that such examples constitute a violation of the Animacy and Referentiality Scales. We believe that the crucial answer hinges on understanding what the precise composition of $1^{\text {st }}$ and $2^{\text {nd }}$ person pronouns is. The fundamental question is whether $1^{\text {st }}$ and $2^{\text {nd }}$ person pronouns are constructed on material which is characteristic to $3^{\text {rd }}$ person animates, or can have an independent structure, which requires an independent type of licensing. We believe that a system under which $1^{\text {st }}$ and $2^{\text {nd }}$ person pronouns can be associated to more than one type of configurations is on the right track and allows us to model and better understand the Old Romance data we started with. More specifically, we propose that both the configurations in (21)/(22)(a) and (b) are possible for $1^{\text {st }}$ and $2^{\text {nd }}$ person pronouns. Following standard assumptions in the literature, we take $2^{\text {nd }}$ person to be signalled by an [ADDRESSEE] feature, while $1^{\text {st }}$ person is flagged by a [SPEAKER] feature.
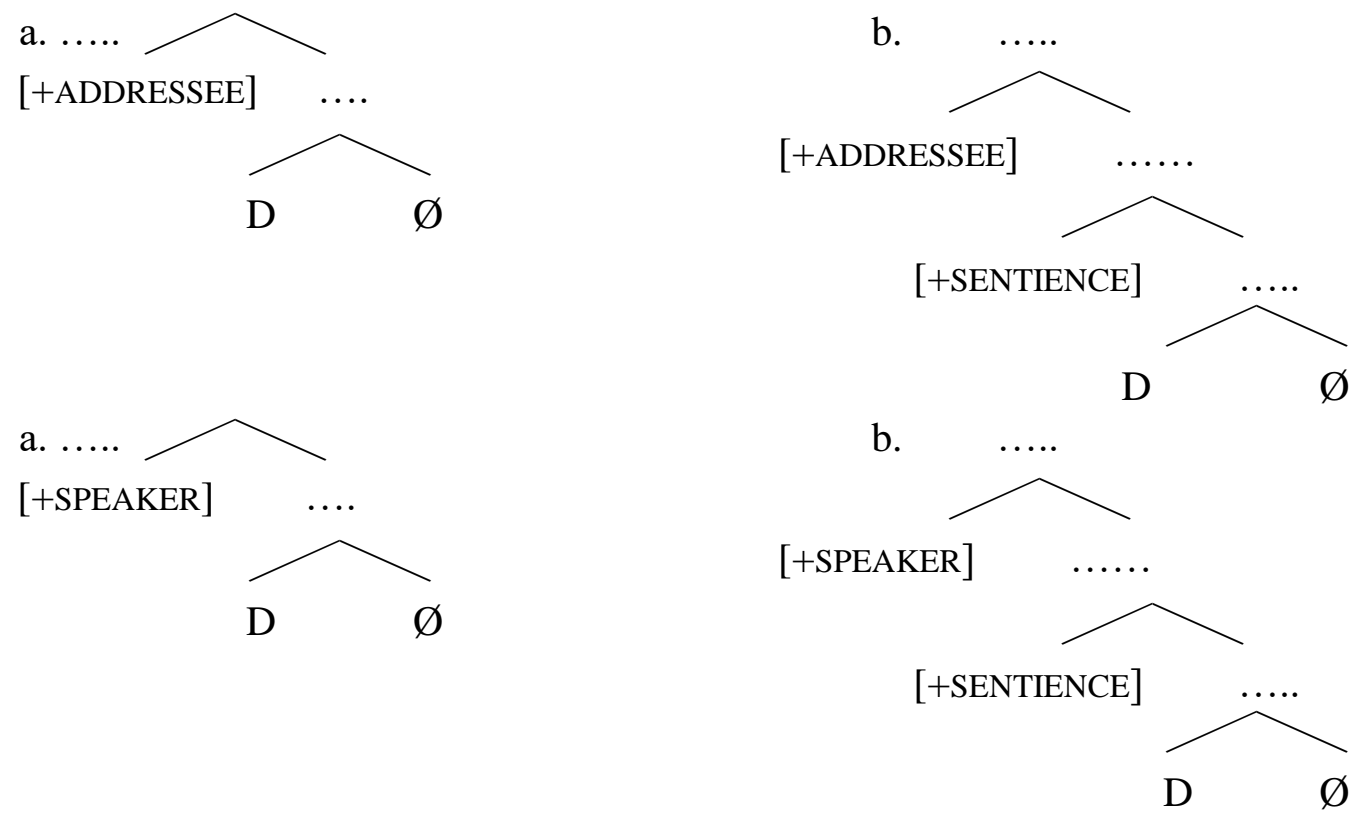

What we see in modern Romance as opposed to old Romance is a shift from a structure of type (a) to a structure of type (b). Initially, the adpositional [DOM] was a marker of animacy, and not signaling Speaker and Hearer. The shift is from a pattern where the Speaker and Hearer specifications got merged with a structure which did not contain structural specification for animacy (Sentience) to a pattern where Speaker and Hearer could get added only to configurations that already contained the Animacy feature. This shift is motivated by a pragmatic constraint that can become grammaticalized in certain languages: Speaker and Hearer can only be animate.

6. Conclusions and some remarks on the status of Scales. The diachronic data we have analyzed in this short paper show a reversal of Scales, in the sense that categories lower down on the Animacy/Referentiality Scale tend to carry DOM to the exclusion of higher ones. We have shown that the data can be explained under a model with assumes the following: i) DOM as a licensing operation beyond [uC]; ii) a fine-grained decomposition of Sentience/Perspectival features, their interaction, and their consequences on syntactic licensing of arguments. Counterarguments to Scales of the type discussed here, as well as of many other types, have led to renewed debates about the nature of such hierarchical generalizations (see especially the discussion in Næss 2004 or Carnie 2005, the latter describing them as 'merely post-factum descriptive statements of grammatical tendencies', a.o.). We believe the lesson we get from the 
data under discussion here is that Scales do not operate in a static system; instead, their interaction with narrow syntax (López 2012, a.o.), nominal licensing strategies, and categorial feature composition is crucial. Moreover, various languages show strong evidence that more than one differential marking strategy is available inside one linguistic system at one given moment. All these interactions might give rise to what look like violations of the Scales.

\section{Corpora}

OLD CATALAN

Corpus Informatitzat del Català Antic (CICA), J. Torruella (dir.), junt amb Manel Pérez Saldanya i Josep Martines. www.cica.cat

OLD ROMANIAN

Bible A: $\quad$ Noul Testament de la Bălgrad (The New Testament from Bălgrad) - 1648, Transylvania

Bible A: $\quad$ Biblie V.T.N.T (The Bible. The Old Testament and the New Testament) - 1688, Walachia (Bucharest)

CC ${ }^{1} .1567$ Coresi, Tâlcul Evangheliilor (The meaning of the Gospels). Ed.: Coresi, Tâlcul Evangheliilor şi molitvenic românesc, ed. V. Drimba, Bucharest: Editura Academiei Române 31-187 (Transylvania, Wallachian Subdialect; Gheţie and Mareş 2001: 115)

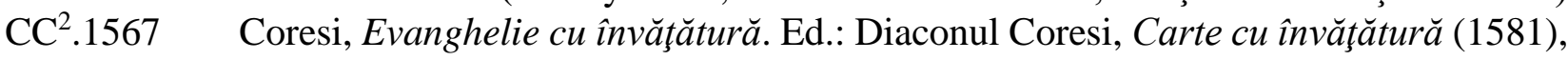
vol. 1, Textul, ed. S. Puşcariu, Al. Procopovici, Bucharest: Socec, 1914. (Braşov)

CT.1560-1 Coresi, Tetraevanghel. Ed. Tetraevanghelul tipărit de Coresi. Braşov 1560-1561, comparat cu Evangheliarul lui Radu de la Măniceşti 1574. Ed. Florica Dimitriu. Bucharest, Editura Academiei. 1963. (Wallachian subdialect, Braşov).

DÎ Documente şi însemnări româneşti din secolul al XVI-lea (Romanian documents and notes from the $16^{\text {th }} \mathrm{c}$ ). Gh. Chivu, M. Georgescu, M. Ioniţă, Al. Mareş, Al. RomanMoraru (eds.), Bucharest: Editura Academiei Române, 1979.

Ev.1642 Evanghelie învăţătoare. Ed. A.-M. Gherman, Bucharest: Editura Academiei Române, 2011, 153-480. (Oltenia: Govora Monastery)

MI 1630 Manuscrisul de la Ieud (The Ieud Manuscript). M. Teodorescu, I. Gheţie (eds.). Bucharest: Editura Academiei, 1977, 153-170. (North Transylvania, Maramureş)

\section{References}

Adger, David \& Daniel Harbour. 2007. Syntax and syncretisms of the Person Case Constraint. Syntax. 10(1). 2-37. https://doi.org/10.1111/j.1467-9612.2007.00095.x.

Aissen, Judith L. 2003. Differential object marking: iconicity vs. economy. Natural Language \& Linguistic Theory 21(3). 435-483. https://doi.org/10.1023/A:1024109008573.

Anagnostopoulou, Elena. 2003. The syntax of ditransitives. Evidence from clitics. Berlin/New York: Mouton de Gruyter.

Avram, Larisa \& Rodica Zafiu. 2017. Semantic hierarchies in the evolution of differential object marking in Romanian. In Adina Dragomirescu et al. (eds.), Sintaxa ca mod de a fi. Omagiu Gabrielei Pană-Dindelegan, la aniversare. 29-42. Bucureşti: Editura Universităţii din Bucureşti.

Béjar, Susana and Milan Rezac. 2009. Cyclic Agree. Linguistic Inquiry 40(1). 35-73. https://doi.org/10.1162/ling.2009.40.1.35.

Beltran, Vicent \& Maribel Guardiola (forthc). Els pronoms personals forts. In Josep Martines \& Manuel Pérez-Saldanya (eds.), Gramàtica del català antic. Barcelona: Empúries. 
Bossong, Georg. 1991. Differential object marking in Romance and beyond. In Dieter Wanner \& Douglas A. Kibbee (eds.), New analyses in Romance linguistics. 43-171. Amsterdam: John Benjamins. https://doi.org/10.1075/cilt.69.14bos.

Cardinaletti, Anna \& Michal Starke. 1999. The typology of structural deficiency. A case study of the three classes of pronouns. In Henk van Riemsdijk (ed.), Clitics in the languages of Europe. 145-233. Berlin: Mouton-De Gruyter.

Carnie, Andrew. 2005. Some remarks on markedness hierarchies. A reply to Aissen (2003). Coyote Working Papers in Linguistics 14. 37-50.

Company, Concepción. 2002. Grammaticalization and category weakness. In Ilse Wischer \& Gabriele Diewald (eds.), New reflections on grammaticalization. 201-215. Amsterdam \& Philadelphia: John Benjamins.

Comrie, Bernard. 1989. Language universals and linguistic typology. Chicago: University of Chicago Press.

Cornilescu, Alexandra. 2000. Notes on the interpretation of the prepositional accusative in Romanian. Bucharest Working Papers in Linguistics 2(1). 91-106.

Cornilescu, Alexandra and Alina Tigău. 2017. On the competition between differentially marked objects and indirevt objects in Romanian. Talk at Going Romance 31 (2017). Bucharest.

Darlymple, Mary and Irina Nikolaeva. 2011. Objects and information structure. Cambridge: Cambridge University Press.

Harley, Heidi and Elizabeth Ritter. 2002. Person and number in pronouns: A feature-geometric approach. Language 78(3). 482-526. https://10.1353/lan.2002.0158.

von Heusinger, Klaus \& Georg Kaiser. 2005. The evolution of differential object marking in Spanish. In Klaus von Heusinger, Georg Kaiser \& Elisabeth Stark (eds.), Proceedings of the workshop "Specificity and the evolution lemergence of nominal determination systems in Romance”. 33-69. Universität Konstanz: Fachbereich Sprachwissenschaft.

von Heusinger, Klaus \& Gáspár Edgar Onea. 2008. Triggering and blocking effects in the development of DOM in Romanian. Probus 20. 67-110. https://doi.org/10.1515/PROBUS.2008.003.

Hill, Virginia \& Alexandru Mardale. 2017. On the interaction of differential object marking and the clitic doubling in Romanian. Revue Roumaine de Linguistique. LXII(4). 393-409.

Irimia, Monica Alexandrina. 2018. Differential objects and other structural objects. Proceedings of the Linguistic Society of America 3. 50:1-15. https://doi.org/10.3765/plsa.v3i1.4345.

Kalin, Laura. 2018. Licensing and differential object marking: the view from Neo-Aramaic. Syntax 21(2). 112-159. https://doi.org/10.1111/synt.12153.

Keine, Stephan. 2010. Case and agreement from fringe to core. A minimalist approach. Berlin/New York: Walter de Gruyter.

Laca, Brenda. 2006. El objeto directo. La marcación preposicional. In Concepción Company (dir.), Sintaxis histórica de la lengua española. Primera parte: La frase verbal, vol. 1. 423-475. Mexico: Fondode cultura económica/Universidad Nacional Autónoma de México.

Levin, Ted. 2019. On the nature of differential object marking: Insights from Palauan. Natural Language \& Linguistic Theory 37(1).167-213. https://doi.org/10.1007/s11049-018-9412-5.

López, Luis. 2012. Indefinite objects: scrambling, choice functions and differential marking. Cambridge, MA \& London: MIT Press.

Mardale, Alexandru. 2015. Differential object marking in the first Romanian texts. In Virginia, Hill (ed.), Formal approaches to DPs in Old Romanian. 200-246. Leiden \& Boston: Brill.

Næss, Ashild. 2004. What markedness marks: the markedness problem with direct objects. Lingua. 114(9-10). 1186-1212. https://doi.org/10.1016/j.lingua.2003.07.005. 
Nevins, Andrew. 2007. The representation of third person and its consequences for person-case effects. Natural Language \& Linguistic Theory. 25(2). 273-313. https://doi.org/10.1007/s11049-006-9017-2.

Nichols, Lynn. 2001. The syntactic basis of referential hierarchy phenomena. Clues from languages with and without morphological case. Lingua 111(4-7). 515-537. https://doi.org/10.1016/S0024-3841(00)00038-3.

Nicula Parashiv, Irina. 2016. The direct object. In Gabriela Pană Dindelegan (ed.), The syntax of Old Romanian. 123-143. Cambridge: Cambridge University Press.

Nikolaeva, Irina. 2014. A grammar of Tundra Nenets. Berlin/New York: de Gruyter.

Ormazabal, Javier and Juan Romero. 2007. The object agreement constraint. Natural Language \& Linguistic Theory 25(2). 315-347. https://doi.org/10.1007/s11049-006-9010-9.

Ormazabal, Javier, and Juan Romero. 2013a. Differential object marking, case and agreement. Borealis: an International Journal of Hispanic Linguistics 2(2). 221-239. https://doi.org/10.7557/1.2.2.2808.

Ormazabal, Javier, and Juan Romero. 2013b. Non accusative Objects. Catalan Journal of Linguistics 12. 155-173. ISSN 1695-6885 (in press); 2014-9719 (online)

Pană-Dindelegan, Gabriela. 2016. Preface. In Pană-Dindelegan, Gabriela (ed.), The syntax of Old Romanian. XXIII-XXVI. Cambridge: Cambridge University Press.

Pensado, Carmen. 1995. El complement directo preposicional: estado de la cuestion y bibliografía comentada. In Pensado, C. (ed.). El CD preposicional. 11-59. Madrid: Visor Libros.

Pineda, Anna (forthc.): El complement directe. In Gramàtica del català antic, ed. by Josep Martines \& Manuel Pérez-Saldanya. Barcelona: Empúries.

Richards, Marc. 1998. Defective agree: Case Alternations, and the prominence of Person. In Marc Richards and Andrej L. Malchukov (eds.), Linguistische Arbeits Berichte (volume on Scales), volume 86. 137-161. Universität Leipzig.

Rodríguez-Mondoñedo, Miguel. 2007. The syntax of objects. Agree and differential object marking. Storrs, CT: University of Connecticut dissertation.

Roegiest, Eugeen. 1979. A propos de l'accusatif prépositionnel dans quelques langues romanes. Vox romanica 38. 312-334. https://doi.org/10.5169/seals-29850.

Rohlfs, Gerard. 1971. Autour de l'accusatif prépositionnel dans les langues romanes: Concordances et discordances. Revue de Linguistique Romaine 35. 312-327. https://doi.org/10.5169seals-399507.

Rosetti, Alexandru. 1978. Istoria limbii române. Editura Ştiinţifică.

Silverstein, Michael. 1976. Hierarchy of features and ergativity. In R. M. W Dixon (ed.), Grammatical categories in Australian languages. 112-171. Canberra: Australian Institute of Aboriginal Studies.

Sornicola, Rosanna. 1997. L'oggetto preposizionale in siciliano antico e in napoletano antico. Italienische Studien 18. 66-80.

http://wpage.unina.it/sornicol/Articoli/OggettoPreposizionaleSicilNapol.pdf.

Sundaresan, Sandhya. 2018. Perspective is syntactic: evidence from anaphora. Glossa 3(1):128.140. https://doi.org/10.5334/gjgl.81.

Torrego, Esther. 1998. The dependencies of objects. Cambridge, MA \& London: MIT Press.

Zubizarreta, Maria Luisa and Roumyana Pancheva. 2017. A formal characterization of personbased alignments. The case of Paraguayan Guaraní. Natural Language \& Linguistic Theory 35(4). 1161-1204. https://doi.org/10.1007/s11049-016-9357-5. 